\title{
Innovating a Model for Measuring Competitiveness in Accordance with the Challenges of Industry 4.0
}

\section{Andrea Okanović ${ }^{1}$, Bojana Jokanović ${ }^{1}$, Vladimir Đaković1, Simonida Vukadinović , Jelena Ješić ${ }^{2}$}

${ }^{1}$ University of Novi Sad, Faculty of Technical Sciences, Trg Dositeja Obradovića 6, 21000 Novi Sad, Serbia, e-mail: andrea.katic@uns.ac.rs; bojanajokanovic@uns.ac.rs; v_djakovic@uns.ac.rs

${ }^{2}$ Educons University, Vojvode Putnika 87, 21208 Sremska Kamenica, Serbia, e-mail: simonida.vukadinovic@educons.edu.rs; jelena.jessic@educons.edu.rs

\begin{abstract}
In the approaching time of the Fourth Industrial Revolution, our planet has undergone dramatic changes, that will leave its mark on all aspects of our life. For this reason, countries around the world have been challenged to reinstate or redefine their national strategies in order to adjust to the requirements of the new age. Policy - makers of today are expected to evaluate each country's readiness to adopt and implement the concepts underlying the Industry 4.0. Analyzing the existing models, it became apparent to the authors and other researchers that there is no suitable model that provides adequate information on the attitude of states towards the criteria of the fourth industrial revolution. For this reason, this paper proposes a new model consisting of 42 quantitative and 8 mixed indicators, 10 of which, directly relate to the characteristics of the new age that is before us. The model has been applied in 17 OECD countries, as it is currently best suited to measure the competitiveness of the most developed countries, which offer the most data within the parameters that describe the characteristics of the smart society of the future. Nevertheless, the authors of the paper believe that the presented model will, very soon, be applicable to a much wider range of countries, and above all, that it will be well suited for measuring the competitiveness of all European countries.
\end{abstract}

Keywords: Fourth Industrial Revolution; smart society; measuring competitiveness; competitiveness indices

\section{Introduction}

During the entire human existence on earth, technology has played one of the most crucial roles in the development of society and civilization. Today, at the beginning of the third decade of the $21^{\text {st }}$ Century, the world is already 
considerably debating the "so-called", Fourth Industrial Revolution, that is expected to introduce significant changes in the way people live and work on a global scale. Looking back on the past, we recall that the first industrial revolution was fueled by the invention of the steam-powered machine, while the second was marked by the use of conveyor belt in the industry and mass electrification. The automation of the production, digitization and use of information and communication technologies was brought by the achievements of the third technological or information revolution. It allowed people to own personal devices for communication and connection with a large number of people, access to information, data storage, control of bank accounts and more. The Fourth Industrial Revolution builds on these inventions and further develops the Internet of Things (IoT), artificial intelligence (AI), 3D printing, robotics, autonomous vehicles, quantum computing, nanotechnology and biotechnology, as well as, new ways to store energy. It is important to distinguish the AI applications, namely, based on the "deepness" of AI: Artificial Narrow Intelligence (ANI), Artificial General Intelligence (AGI) and Artificial Super Intelligence (ASI). Scientists are emphasizing that the Fourth Industrial Revolution, which brings together the physical, digital and biological characteristics of products, will bring dramatic changes to the world in the course of the next twenty years, such as have not been seen in the previous hundred [1]. According to a survey, as many as $65 \%$ of children who enroll in primary school today will be doing jobs that still do not exist today [2]. Authors Pereira \& Romero define Industry 4.0 concept "as an umbrella term for a new industrial paradigm that embraces a set of future industrial developments regarding Cyber-Physical Systems (CPS), Internet of Things (IoT), Internet of Services (IoS), Robotics, Big Data, Cloud Manufacturing and Augmented Reality". Industry 4.0 is being predominantly shaped by two main drivers: Cyber-Physical Systems and the Internet of Things and Services [3]. Today's highly equipped factories use autonomous robot for work in the places where human workers are restricted to work as well as to perform autonomous production method more precisely [4]. However, the purchase and use of autonomous vehicles and robots and the R\&D activity of these new transportation devices might differ in countries. The same is applicable in the field of quantum computing, nanotechnology, biotechnology and energy storage.

The OECD countries brings together the most developed group of countries in the world, composed of 36 member countries today. In its strategies, like the OECD Jobs Strategy and the OECD Skills Strategy, this organization emphasizes that today's technological advancements have an impact on society, the economy and the way of life of people like never before, and that we are living in a transformative age where disruption is the new norm $[5,6]$. It is important to emphasize that, in the context of dramatic changes in technology, the aforementioned strategies emphasize that sustainable development must be an integral element of the growth and achievement of high competitiveness of its member countries. 
In order to trace the envisaged goals in the most appropriate way, at a time when the Fourth Industrial Revolution has already set its challenges, this paper proposes a new model for measuring competitiveness in accordance with the challenges of the Industry 4.0. The new model builds on previous research by the authors and offers an advanced selection of indicators in accordance with the requirements of the new wave of change $[7,8,9]$. Specifically, by examining existing traditional models for measuring macro-level competitiveness, it has been found that they do not sufficiently include indicators relating to the domain of industry $4.0[7,10$, 11]. The main hypothesis of the research reads: The new model of competitiveness measurement provides a more adequate measurement of the position of today's most developed countries because it takes into consideration the challenges of the present as well as of the time that is before us, i.e. the Fourth Industrial Revolution. The subhypothesis of the paper reads: There are subindexes that have a small - scale range of variation and variance, as well as those with more pronounced differences between the worst and the best ranked economy. The mathematical and statistical research methods needed to structure and subsequently test the set model of competitiveness measurement were used in the paper. An analysis of the obtained results and discussions regarding the position of the countries included in the survey were completed, which is also seen as the outcome of this paper.

\section{Conceptual Background}

Industrial revolutions have brought upon the world, the economic development, growth of world wealth, increase of leisure fund as well as longer life span of people. Each new revolution brings with it many changes that represent a potential chance for the success of those who know how to manage them, but also a threat to those who do not possess the necessary skills. Today, in order to achieve high competitiveness, at all levels (micro, macro and meso), it is important to be accustomed to the world trends, as much as it is to take part in their creation, in order to secure the highest positions in the rankings. When it comes to measuring competitiveness, it is important to emphasize that sustained innovation of the existing models and rarely their reinvention is essential for being in accordance with the meet challenges of today as well as of tomorrow.

As far back as 1969, Drucker defined the most competitive society as the "Knowledge Society" or "Society of Mobility" [12]. Somewhat later, the OECD (1996) defined a knowledge-based economy as the "one in which production, distribution and use of knowledge are the main drivers of growth, wealth creation, and employment for all industries" [13]. It is during this period, but also in the coming years, that an expansion of various researches takes place, whose authors have tried to define the parameters that measure the success of states, or the 
indicators according to which the countries of a society based on knowledge, innovation and technological progress are ranked $[13,14,15,16]$. In their previous studies, the authors of the paper extracted 23 composite indices containing the parameters of the Knowledge Society and, on the basis of further research, offered a model for measuring competitiveness at the macro level, consisting of 65 quantitative indicators $[7,8]$. On this occasion, they pointed out that the most important parameters for measuring the success of a knowledgebased society are: high percentage of highly educated population, large government investments in education, science and research, promotion of lifelong learning, high quality and accessible information and communication infrastructure and services, propulsive and competitive economy, sustainable technological development, wide availability of information and easy access to them.

Further advancements of Science and Technology generates new changes to the world, as well as, the need to improve models for measuring competitiveness. The concept underlying the onset of a new revolution wave originated in Germany under the name "Industry 4.0", and the whirlwind soon spread to other highly developed countries such as the United Kingdom, which recognized it as the "Fourth Industrial Revolution" [17, 18, 19]. Industry 4.0 is also associated with terms like "smart factory", "smart manufacturing", "advanced manufacturing" and the like $[10,20]$. The issue of competitive advantage of nations, regions and companies is a topic of crucial interest for policy makers, scientists and managers worldwide. Professor Klaus Schwab, Founder and Executive Chairman of the World Economic Forum, has published a book entitled The Fourth Industrial Revolution, outlining three groups of interconnected megatrends that will mark the future. These include physical, biological, and digital megatrends. Physically they include advanced robotics, autonomous vehicles, 3D printing and the development of new materials. Biological megatrends include biotechnology and genome projects. Digital megatrends refer to artificial intelligence, the Internet of Things, blockchain technology, cloud memory and virtual reality [1]. If the predictions are true, the consequences of the changes described will be multifaceted, and will primarily affect the global economy, demographics, education, quality of life and work, etc. Futurologists tell us that one third of today's children will live longer than 100 years because they will have better options for preventing and treating the diseases [21]. Furthermore, research shows that one has to be very careful about choosing a profession today, because, for example, the job of a journalist will be partially jeopardized by the possibility of popularizing news writing programs, which could replace more than $90 \%$ of practitioners, by 2025 , by writing newspaper articles. Such changes would have implications for working life, the pension system, as well as, individual life planning [22]. According to Vacek, "the deep impact of Industry 4.0 on socioeconomic issues can be called Society 4.0" [23]. 
Through a literature review several new models were discovered that rely on the latest developments in the technique (Table 1) [24, 25, 26, 27, 28]. However, although there are published models relating to evaluation of competitiveness in the context of the fourth industrial revolution at the macro level, it can be noted that they rely largely on qualitative data whose objectivity is difficult to verify. In previous research done by the authors it was shown that the qualitative indicators can be subject of manipulative influences of experts so it was suggested that quantitative parameters are more reliable measures for competitiveness models in general [29]. Other authors have reached a similar conclusion. Specifically, Batchkova et al. conclude that in the models they have analyzed, which refer to the competitiveness indices of Industry 4.0, there are no quantitative indicators describing the main concepts, and that they are used instead of qualitative ones, and that there is a high degree of unpredictability in the information on which this evaluation is based [30].

We can conclude, from the aforementioned, that with the advent of a new, fourth industrial revolution, the models proposed to measure the competitiveness of certain entities must be re-examined and improved. The paper below proposes a new model for measuring competitiveness based on the requirements of the fourth industrial revolution. However, the usage or development of Extended Reality (Virtual, Augmented and Mixed Reality) as a significant parameter, is not mentioned in the model, due to a lack of data.

Table 1

Industry 4.0 competitiveness index overview

\begin{tabular}{|c|c|c|c|}
\hline Index name & $\begin{array}{l}\text { Authors and } \\
\text { year of } \\
\text { publishing } \\
\end{array}$ & Level & Data \\
\hline $\begin{array}{l}\text { The Singapore } \\
\text { Smart Industry } \\
\text { Readiness Index }\end{array}$ & $\begin{array}{l}\text { Economic } \\
\text { Development } \\
\text { Board, } 2017 . \\
\end{array}$ & $\begin{array}{l}\text { Micro } \\
\text { level }\end{array}$ & $\begin{array}{l}\text { qualitative data; } 3 \text { subindexes: } \\
\text { Process, Technology, } \\
\text { Organization; } 16 \text { indicators }\end{array}$ \\
\hline $\begin{array}{l}\text { Metamodel for } \\
\text { Evaluating } \\
\text { Enterprise } \\
\text { Readiness in the } \\
\text { Context of Industry } \\
4.0\end{array}$ & $\begin{array}{l}\text { Basl, J., \& } \\
\text { Doucek, P, } \\
2019 .\end{array}$ & $\begin{array}{l}\text { Micro } \\
\text { level }\end{array}$ & $\begin{array}{l}7 \text { subindexes: Society, Area of } \\
\text { society, Branch of area of society, } \\
\text { Enterprise, Area of enterprise, } \\
\text { Dimension of enterprise area, } \\
\text { Subdimension of enterprise area }\end{array}$ \\
\hline $\begin{array}{l}\text { RB Industry } 4.0 \\
\text { Readiness Index }\end{array}$ & $\begin{array}{l}\text { Rolland } \\
\text { Berger, } \\
2014 .\end{array}$ & $\begin{array}{l}\text { Macro } \\
\text { level, } 22 \\
\text { courtiers }\end{array}$ & $\begin{array}{l}\text { qualitative data; } 2 \text { subindexes: } \\
\text { Industrial excellence, Value } \\
\text { network }\end{array}$ \\
\hline $\begin{array}{l}\text { Readiness for the } \\
\text { Future of } \\
\text { Production }\end{array}$ & $\begin{array}{l}\text { World } \\
\text { Economic } \\
\text { Forum, } \\
2018 .\end{array}$ & $\begin{array}{l}\text { Macro } \\
\text { level, } \\
100 \\
\text { countries }\end{array}$ & $\begin{array}{l}\text { qualitative and quantitative data; } 6 \\
\text { subindexes: Technology \& } \\
\text { Innovation, Human Capital, Global } \\
\text { Trade \& Investment, Institutional } \\
\text { Framework, Sustainable } \\
\text { Resources, Demand Environment; } \\
32 \text { qualitative indicators and } 27 \\
\text { quantitative indicators }\end{array}$ \\
\hline
\end{tabular}




\begin{tabular}{|l|l|l|l|}
\hline Industry 4.0 & Danish & Macro & quantitative data; 7 subindexes: \\
Readiness Index & $\begin{array}{l}\text { Institute of } \\
\text { Industry 4.0, }\end{array}$ & $\begin{array}{l}\text { level, } \\
120 \\
\text { courtiers }\end{array}$ & $\begin{array}{l}\text { Innovation aptitude, Demand } \\
\text { factors, Driving forces, Enterprise } \\
\text { excellence, Basic enablers, } \\
\text { Technological sophistication, } \\
\text { Industry 4.0 specific enablers; 24 } \\
\text { indicators }\end{array}$ \\
\hline
\end{tabular}

Source: the authors

\section{Methodology}

The paper used a model based on the proposed methodology of well-known authors [14]. The survey involves the collection of secondary data obtained mainly from official statistical reports or from representative institutions. Further steps are related to the formation of thematic indicators, weighting, the calculation of average values, the processing of time series, and the use of regression and correlation analysis [14]. All in all, to form a composite index it is necessary to follow the following steps: development of a thematic framework; selecting indicators, adjusting irreversible data and replacing missing data; selecting a sample of countries; formation of thematic subindicators; standardization and weighting of indicators; aggregation and ranking of countries by subindicators; subindicator weighting; aggregation and formation of composite index; composite Index evaluation [14]. Finally, it is important to stress that the model does not necessarily adhere sequentially to all steps above, they are rather undertaken simultaneously, in many cases [31].

\section{Data and Results}

\subsection{Construction of a Thematic Framework}

The first step in the construction of a composite index is to define a theoretical framework that describes the phenomenon to be quantified. For this purpose, it is necessary to carry out a detailed literature review so that indicators that accurately measure macro-level competitiveness can be extracted later [14, 32].

The choice of indicators used in the research reflects the challenges of today and the future, that is, the fourth technological revolution. The presented model contains a set of indicators, within the subindex called Smart Society, representing world trends such as those measuring the use of autonomous vehicles, artificial intelligence, the use of robots, 3D printing, as well as IoT [10, 33, 34, 35]. 
Alongside them, traditional indicators are being used today to measure the use of information and communication technologies among the population and in enterprises, followed by indicators of a knowledge economy, innovation and $\mathrm{R} \& \mathrm{D}$, as well as, indicators of sustainable development.

\subsection{Selecting Indicators, Adjusting Irreversible Data and Replacing Missing Data}

In order to make a relevant choice of indicators, several of their key features, such as validity, measurability and availability of data, need to be taken into consideration. These characteristics are very important because in practice it often happens that the reliability of the data itself is called into question, i.e., it is not known how certain organizations and institutions collected them. For this reason, care should be taken to use only the data published by the relevant authorities. When it comes to measurability, the problem arises with certain research-relevant phenomena for which there are no statistical data or quantitative indicators [29]. For this reason, many researchers resort to the use of qualitative data based on the opinions of a narrow circle of evaluation experts. However, as shown in the paper, their use has many drawbacks and can lead to erroneous evaluations, results and conclusions [29]. Third crucial feature related to data is their availability. The importance of this feature stems from the fact that certain data are very difficult to obtain i.e. not being publicly visible, institutions that evaluate them do not display them clearly or ask for large sums of money for their use.

The model presented in the paper consists mainly of quantitative indicators, while mixed indicators are far less used, i.e. data in the form of previously measured composite indices. In order to obtain an objective comparison between countries of different sizes, it is ultimately important to adjust the data according to population, income, land size, etc.

In order to present national competitiveness in the best possible way in light of the fourth industrial revolution, the proposed model contains a set of 50 indicators, of which 42 are quantitative indicators and 8 are mixed (previously measured composite indices) (Table 2). The paper uses official statistics from relevant institutions that are published in their statistical yearbooks or websites. The majority of data was obtained from institutions such as: the World Bank, the International Telecommunication Union (ITU), the UNECO portal - UIS.Stat and the OECD statistical portal, referring to calendar years 2017 and 2018. The major issue with the survey was the choice of parameters for the Smart Society subindicator, as many new trends are not yet covered by the statistical measurements of the relevant institutions.

Indicators numbered 12, 14, 23, 43, 45, 48 and 49 stand for irreversible measures in which lower values indicate a higher level of development. For this reason, it is necessary to transform them according to the following formula: 
Xtrans $=2 *(X \max -X \min )-X i$

As has been pointed out on many occasions before, one of the main problems with the selection of adequate indicators is the lack of available data [8, 14]. Namely, it is often the case that individual statistical databases do not have complete data for all countries described in the survey, and in such a situation it is necessary to use the "nearest neighbor" method, which means that values are estimated on the most similar basis. Of course, this rule should be used as scarcely as possible.

\subsection{Country Sample Selection}

The new composite index model has been implemented in selected countries by The Organization for Economic Co-operation and Development. The following countries were selected for the survey: Sweden (SE), Norway (NO), Finland (FI), Germany (DE), China (CN), South Korea (KR), United States (USA), Italy (IT), France (FR), Poland (PL), Russia (RU), United Kingdom (UK), Spain (ES), Netherlands (NL), Japan (JP), Austria (AT) and Czech Republic (CZ).

The countries selected to apply the new competitiveness index are represented by 17 representative OECD members, established in 1961 with the aim of boosting the global economy and trade. Today, the OECD brings together 36 member countries, most of which are developed countries, recording achievements in all areas and showing high results according to numerous rankings and measurements of their competitiveness. These 36 countries are responsible for as much as, $42.8 \%$ of world GDP [58].

\subsection{Creation of Thematic Subindices}

The new composite index model presented consists of 50 indices that are classified into five thematic subindices under the following names: Smart Society, Society of Good Chances, Networked Society, Knowledge Society and Sustainable Society (Table 2). Smart Society subindicator measures the impact the latest industry 4.0 technologies have on today's smart society. They occupy the positions from 1 to 10 in the List of Indicators. Society of Good Chances subindicator refers to the economic and entrepreneurial conditions that companies face in doing business. In the list of indicators, they occupy the $11^{\text {th }}$ to the $17^{\text {th }}$ positions. Networked Society subindicator represents a measure of the extent of communication between people and companies. This subindicator assesses the basic conditions for establishing communication, as well as its frequency. In the list of indicators, they occupy the $18^{\text {th }}$ to the $25^{\text {th }}$ positions. Knowledge Society subindicator refers to the development of an effective innovation climate in companies, universities and other research institutions. These measures also describe the population situation in higher education, employment in the technology sector, as well as government and private sector allocations for R\&D. 
In the list of indicators, they occupy the $26^{\text {th }}$ to the $42^{\text {nd }}$ positions. Sustainable Society subindicator describes a measure of the environmental impact of society's development, as well as ways in which people can contribute to a greater degree of sustainable development. In the list of indicators, they occupy from the $43^{\text {rd }}$ to the $50^{\text {th }}$ position.

Table 2

List of indicators

\begin{tabular}{|c|c|c|}
\hline No. & $\begin{array}{c}\text { Name of } \\
\text { subindicator }\end{array}$ & Name of indicator \\
\hline 1 & \multirow{10}{*}{$\begin{array}{l}\text { Smart } \\
\text { Society }\end{array}$} & $\begin{array}{l}\text { IoT (The Internet of Things) devices online (per } 100 \text { inhabitants) } \\
{[36,37]}\end{array}$ \\
\hline 2 & & Artificial Intelligence Index [38] \\
\hline 3 & & Government Artificial Intelligence Readiness Index [39] \\
\hline 4 & & Autonomous Vehicles Readiness Index [40] \\
\hline 5 & & Electric vehicles charging stations (per million inhabitants) [41] \\
\hline 6 & & The Automation Readiness Index [42] \\
\hline 7 & & Use of cloud computing (\% enterprises) [43] \\
\hline 8 & & 3D Printing Country Index [44] \\
\hline 9 & & $\begin{array}{l}\text { Estimated annual shipments of multipurpose industrial robots (per } \\
\text { million inhabitants) [45] }\end{array}$ \\
\hline 10 & & Robots in manufacturing industry (per 10,000 employees) [45] \\
\hline 11 & \multirow{7}{*}{$\begin{array}{c}\text { Society of } \\
\text { Good } \\
\text { Chances }\end{array}$} & GDP per capita (current US\$) [46] \\
\hline 12 & & Ease of doing business index [46] \\
\hline 13 & & $\begin{array}{l}\text { New business density (new registrations per 1,000 inhabitants ages } \\
\text { 15-64) [46] }\end{array}$ \\
\hline 14 & & Time required to start a business (days) [46] \\
\hline 15 & & Foreign direct investment, net outflows (\% of GDP) [46] \\
\hline 16 & & Foreign direct investment, net inflows (\% of GDP) [46] \\
\hline 17 & & Logistics performance index [46] \\
\hline 18 & \multirow{8}{*}{$\begin{array}{l}\text { Networked } \\
\text { Society }\end{array}$} & Individuals using the Internet (\% of population) [46] \\
\hline 19 & & Fixed broadband subscriptions (per 100 inhabitants) [46] \\
\hline 20 & & $\begin{array}{l}\text { Number of active mobile-broadband subscriptions (per } 100 \\
\text { inhabitants) [47] }\end{array}$ \\
\hline 21 & & Secure Internet servers (per million inhabitants) [46] \\
\hline 22 & & E-Participation Index [48] \\
\hline 23 & & Rates for broadband internet in PPP \$/monthly [49] \\
\hline 24 & & Countries releasing most app (per million inhabitants) [50] \\
\hline 25 & & $\begin{array}{l}\text { Country distribution of active online workers (by population share) } \\
\text { [51] }\end{array}$ \\
\hline 26 & \multirow{3}{*}{$\begin{array}{l}\text { Knowledge } \\
\text { Society }\end{array}$} & Highly educated population (in \% of people $30-34$ years old) [52] \\
\hline 27 & & Government expenditure on education, total (\% of GDP) [46] \\
\hline 28 & & School enrollment, tertiary (\% gross) [46] \\
\hline
\end{tabular}




\begin{tabular}{|c|c|c|}
\hline 29 & & Graduates in science \& engineering (\% gross) [53] \\
\hline 30 & & $\begin{array}{l}\text { Enrollment in tertiary education - PhD students - ISCED } 8 \text { (per } \\
\text { million inhabitants) [53] }\end{array}$ \\
\hline 31 & & Gross expenditure on R\&D (\% GDP) [53] \\
\hline 32 & & $\begin{array}{l}\text { Gross expenditure on R\&D: Performed by business enterprise (\% } \\
\text { of GDP) [53] }\end{array}$ \\
\hline 33 & & $\begin{array}{l}\text { Science, technology and innovation: total R\&D personnel (per } \\
\text { million inhabitants) [53] }\end{array}$ \\
\hline 34 & & $\begin{array}{l}\text { Employment in technology and knowledge-intensive sectors (\% } \\
\text { workforce) [53] }\end{array}$ \\
\hline 35 & & $\begin{array}{l}\text { Labor force with advanced education (\% of total working-age } \\
\text { population with advanced education) [46] }\end{array}$ \\
\hline 36 & & ICT goods imports (\% total goods imports) [46] \\
\hline 37 & & ICT goods exports (\% of total goods exports) [46] \\
\hline 38 & & High-technology exports (\% of manufactured exports) [46] \\
\hline 39 & & $\begin{array}{l}\text { Scientific and technical journal articles (per million inhabitants) } \\
\text { [46] }\end{array}$ \\
\hline 40 & & Patent applications (per million inhabitants) [55] \\
\hline 41 & & Patent applications per GDP [55] \\
\hline 42 & & Patent grants [55] \\
\hline 43 & \multirow{8}{*}{$\begin{array}{l}\text { Sustainable } \\
\text { Society }\end{array}$} & CO2 emissions (metric tons per capita) [46] \\
\hline 44 & & Alternative and nuclear energy (\% of total energy use) [46] \\
\hline 45 & & Electric power consumption (kWh per capita) [46] \\
\hline 46 & & $\begin{array}{l}\text { Renewable internal freshwater resources per capita (cubic meters) } \\
\text { [46] }\end{array}$ \\
\hline 47 & & $\begin{array}{l}\text { Renewable energy consumption (\% of total final energy } \\
\text { consumption) [46] }\end{array}$ \\
\hline 48 & & $\begin{array}{l}\text { PM2.5 air pollution, mean annual exposure (micrograms per cubic } \\
\text { meter) [46] }\end{array}$ \\
\hline 49 & & Municipal waste total (kilograms per capita) [52] \\
\hline 50 & & Recycling rate of municipal waste $(\%)[56,57]$ \\
\hline
\end{tabular}

Source: the authors

\subsection{Indicator Standardization, Weights, Aggregation and Ranking of Countries by Subindicators}

During data collection, we come across different units of measure that measure different indicators. In order to avoid mixing such values, it is necessary to normalize or standardize the data obtained. In practice, there are different techniques that can be applied, each with its own advantages and disadvantages and can produce different research results [14]. The paper presents a data standardization technique that gives an average of 100 for all variables. 
$S i j=\frac{X i j}{\bar{x}} * 100$

where $s_{i j}$ is standardized value of the $j$-th indicator of indicator $i$-th of state; $x_{i j}$ is value of the $j$-th indicator of indicator of the $i$-th state; $\bar{x}_{j}$ is average value of the $j$ th indicator.

The next step in obtaining relevant values is the assignment of weights. Weight values or weights are assigned to emphasize the importance of individual indicators and subindicators when constructing a composite index. There are several methods used for this purpose. These include regional analysis, principal component analysis, factor analysis, etc. [14]. In addition to the aforementioned methods, weight values can be assigned based on the analysis of experts in the analyzed areas, as well as on the quality and availability of the data obtained. It is important to point out that none of the above methods is completely reliable, and that different weighting techniques give different end results in measuring the competitiveness of countries. For this reason, some authors believe that this step should not be applied and that all factors should have the same weight value [31, 59]. However, the authors of this paper are of the view that weighting should be done for the reasons already mentioned. The weighting of individual indicators was carried out in accordance with their importance, in the opinion of the authors, within each of the five subindicators presented. In final step, the aggregation or summing up of values after standardization and weighting is performed, which results in the formation of results according to thematic indicators or subindicators.

\subsection{Subindicator Weighting, Aggregation and Formation of the Competitiveness Index}

The largest weights are assigned to the Smart Society subindex (25\%) and the Knowledge Society subindex (25\%) because these two groups of parameters contain a large number of individual indicators but also have the greatest impact on the competitiveness of today's smart society in which we live. The subindexes Networked Society and Sustainable Society are assigned a weighting value of $17 \%$, while the subindex Society of Good Chances has a weighting of $13 \%$. As a reason for this method of assigning weights, we can state the author's estimated impact of the indicators themselves and the groups of indicators on society 4.0, as well as the number of individual indicators within the subindicators. Table 3 shows the values for each analyzed country according to the 5 subindicators. As can be seen from Table 3 and Figure 1, South Korea stands out as the leader according to the subindices Smart Society and Knowledge Society, while USA, stands out as having the best performance, within the subindex that describes the conditions for entrepreneurship, i.e. the Society of Good Chances. Within the Networked Society, Netherlands dominates but with almost the same result in the Norway and Finland. In the Sustainable Society subindex Norway is the undisputed leader. 
The final result was obtained as the sum of 5 weighted subindicators under the names: Smart Society (SmS), Society of Good Chances (SGC), Networked Society (NS), Knowledge Society (KS) and Sustainable Society (SuS). Table 3 shows the weighted values of each subindex for each analyzed country, as well as the aggregation and formation of the total composite index result, or the final ranking of the countries considered in the survey.

Table 3

Composite index - assigning weight coefficients to subindices and aggregation and formation of the competitiveness index

\begin{tabular}{|l|l|l|l|l|l|l|l|}
\hline Comp. subind. & SmS & SGC & NS & KS & SuS & $\begin{array}{l}\text { Comp. } \\
\text { index }\end{array}$ & \\
\hline Weight: & 0.25 & 0.13 & 0.20 & 0.25 & 0.17 & Rank \\
\hline SE & 31.94 & 15.52 & 25.14 & 27.79 & 23.81 & 124.20 & 3 \\
\hline NO & 29.92 & 16.83 & 27.67 & 21.66 & 37.90 & 133.98 & 2 \\
\hline FI & 28.00 & 14.71 & 27.08 & 26.72 & 21.06 & 117.57 & 5 \\
\hline DE & 32.21 & 13.79 & 18.95 & 26.20 & 14.95 & 106.09 & 7 \\
\hline CN & 18.15 & 8.63 & 11.38 & 31.53 & 12.12 & 81.80 & 12 \\
\hline KR & 53.98 & 12.03 & 16.29 & 46.97 & 14.16 & 143.43 & 1 \\
\hline USA & 32.94 & 18.64 & 25.15 & 31.02 & 12.16 & 119.90 & 4 \\
\hline IT & 20.66 & 10.08 & 16.21 & 14.27 & 15.30 & 76.52 & 15 \\
\hline FR & 20.42 & 11.52 & 17.58 & 33.51 & 17.01 & 100.04 & 9 \\
\hline PL & 9.04 & 10.92 & 15.70 & 14.76 & 13.46 & 63.87 & 17 \\
\hline RU & 10.15 & 10.59 & 13.51 & 15.31 & 19.05 & 68.61 & 16 \\
\hline UK & 21.81 & 15.79 & 24.06 & 20.14 & 14.65 & 96.46 & 10 \\
\hline ES & 21.21 & 11.70 & 17.39 & 14.31 & 14.89 & 79.50 & 14 \\
\hline NL & 29.10 & 12.81 & 28.46 & 22.17 & 12.99 & 105.54 & 8 \\
\hline JP & 27.21 & 12.30 & 19.11 & 33.99 & 13.88 & 106.49 & 6 \\
\hline AT & 21.83 & 12.76 & 18.98 & 25.00 & 17.54 & 96.10 & 11 \\
\hline CZ & 16.43 & 12.37 & 17.35 & 19.64 & 14.09 & 79.88 & 13 \\
\hline
\end{tabular}

Source: the authors

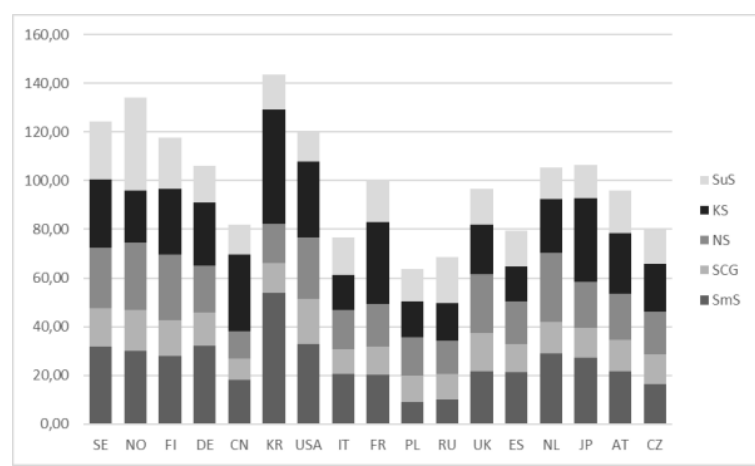

Figure 1

Source: the authors

Composite index and subindexes 
The conducted research shows that South Korea is by far the first in the list according to the Competitiveness Index of the Society 4.0 with a total of 143.43 index points. It especially stood out on indicators that measure the competitiveness of states in the smart and knowledge society. Norway is on the second place (133.98), being an unprecedented leader according to the Sustainable Society subindicator. Sweden (124.2), USA (119.9) and Finland (117.57) took the third, fourth and fifth place, showing exceptional performance in the Smart Society subindices. Japan (106.49), although the high-performing scorer in several fields, ranked 6th in the ranking of the composite index, primarily due to slightly worse results in the field of entrepreneurship and sustainable development. It is followed by several countries with small differences in points, namely: Germany (106.09) and Netherlands (105.54) which scores best according to the Smart Society subindex, France (100.04) which has shown exceptional performance in terms of Knowledge Society, United Kingdom (96.46) which stands out according to the subindicator Networked Society and Austria (96.10). They are followed by the China (81.8), the Czech Republic (79.88), Spain (79.5), Italy (76.52), while Russia (68.61) and Poland (63.87) are in below-average positions. Although today, China stands out as a leader in innovation and technological development, according to this composite index it did not occupy the highest positions, primarily due to the adjustment of indicators in proportion to the population. For example, if we look at the number of patent applications (residents), we can see that China is the global leader with 1,245,709 patent applications in 2017, which is more than half of the 2,161,610 patents reported in that year as a whole in the entire world. However, if adjusted according to population, countries such as South Korea (3119 patents per million population) and Japan (2041 pence per million population) have far better results than China (888 patents per million population) in 2017 [46].

\subsection{Testing the Composite Indicator}

Considering that the choice of statistical methods influences the end result, it is necessary to test the composite index. This step involves several tests, such as uncertainty and sensitivity tests, to understand the impact of certain variables, weights, and standardization techniques on the overall score or rank of the countries analyzed. In this way it is possible to evaluate the quality of the methods used and to improve it. Regression and variance methods were used as in [14].

\subsubsection{Regression Analysis Based on the Indicators of Economic Dynamism}

An economic dynamism indicator can show how, for example, GDP per capita affects the end result. To obtain such an indicator, we must first standardize the value of the composite index using the "minimum-maximum" method [14]. With this step, we get transformed values that range between zero (minimum value) and one (maximum value). That way, we will be able to get a picture of the state of a 
country's distance from its best and worst position. Otherwise, the standardization itself does not affect the ranking of countries according to certain indicators. The following step is to calculate the indicators of economic dynamism (ECi) using the following formula:

$E C i=G D P i *(1+y i)$

where $y i$ is a common composite index in relation to the difference between maximum and minimum, and GDP $i$ is GDP per capita in USD thousands. The obtained results are shown in Table 4 and Figure 2, which shows a comparison between the country rankings obtained from calculations of The Competitiveness Index of the Society 4.0 and the indicator of economic dynamism. Although, in most countries, similar results were obtained in the ranking, large oscillations are present in some countries, such as South Korea, which ranked on the $8^{\text {th }}$ in this way compared to the $1^{\text {st }}$ place, it was ranked as, according to The Competitiveness Index of Society 4.0 (CIS 4.0). On the other hand, USA jumped from the $4^{\text {th }}$ to the $2^{\text {nd }}$ place, the Netherlands from the $8^{\text {th }}$ to the $5^{\text {th }}$, Austria from the $11^{\text {th }}$ to the $7^{\text {th }}$, and Italy from the $15^{\text {th }}$ to the $12^{\text {th }}$.

Table 4

Composite Competitiveness Index of the Society 4.0 and indicator of economic dynamism - ranking of countries

\begin{tabular}{|l|l|l|l|l|l|l|}
\hline Country & \multicolumn{1}{|c|}{$\begin{array}{c}\text { 4.0 } \\
\text { type I }\end{array}$} & $\begin{array}{c}\text { CIS 4.0 in } \\
\text { relation to the } \\
\text { difference } \\
\text { between max. } \\
\text { and mini. }\end{array}$ & $\begin{array}{c}\text { GDP per } \\
\text { capita in } \\
\text { USD } \\
\text { thousands }\end{array}$ & $\begin{array}{c}\text { Indicator } \\
\text { of } \\
\text { Economic } \\
\text { Dynamism }\end{array}$ & $\begin{array}{l}\text { RANK } \\
\text { type II }\end{array}$ \\
\hline SE & 124.20 & 3 & 0.758 & 54,112 & 95,146 & 3 \\
\hline NO & 133.98 & 2 & 0.881 & 81,807 & 153,903 & 1 \\
\hline FI & 117.57 & 5 & 0.675 & 49,960 & 83,683 & 4 \\
\hline DE & 106.09 & 7 & 0.531 & 48,195 & 73,772 & 6 \\
\hline CN & 81.80 & 12 & 0.225 & 9,770 & 11,972 & 16 \\
\hline KR & 143.43 & 1 & 1.000 & 31,362 & 62,724 & 8 \\
\hline USA & 119.90 & 4 & 0.704 & 62,641 & 106,755 & 2 \\
\hline IT & 76.52 & 15 & 0.159 & 34,318 & 39,773 & 12 \\
\hline FR & 100.04 & 9 & 0.455 & 41,463 & 60,313 & 10 \\
\hline PL & 63.87 & 17 & 0.000 & 15,424 & 15,424 & 15 \\
\hline RU & 68.61 & 16 & 0.060 & 11,289 & 11,962 & 17 \\
\hline UK & 96.46 & 10 & 0.410 & 42,491 & 59,894 & 11 \\
\hline ES & 79.50 & 14 & 0.196 & 30,323 & 36,279 & 13 \\
\hline NL & 105.54 & 8 & 0.524 & 52,978 & 80,725 & 5 \\
\hline JP & 106.49 & 6 & 0.536 & 39,287 & 60,334 & 9 \\
\hline AT & 96.10 & 11 & 0.405 & 51,512 & 72,380 & 7 \\
\hline CZ & 79.88 & 13 & 0.201 & 22,973 & 27,597 & 14 \\
\hline
\end{tabular}

Source: the authors 


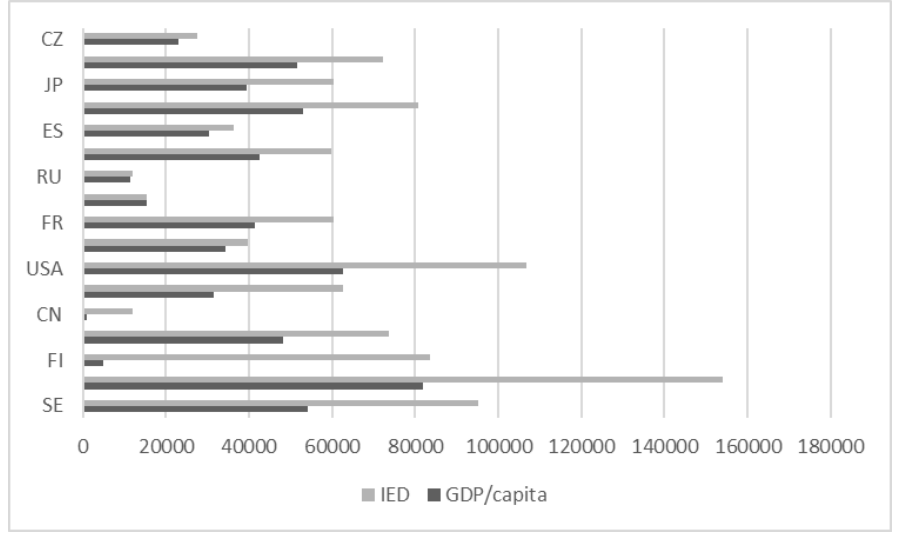

Source: the authors

Figure 2

Indicator of Economic Dynamism

\subsubsection{Analysis of the Range of Variation and Variance}

The analysis of the range of variation and variance (Table 5, Figure 3) shows the differences between the best and worst ranked countries by composite subindicators. Standard deviation is an indicator that shows us the average deviation from the average value, while the coefficient of variation shows the relationship between the standard deviation and the average value. From this analysis, we can see that some parameter groups have smaller ranges of variation, while others have larger ranges.

The subindices Smart Society (44.95) and Networked Society (32.70) have the biggest differences between the best and worst-ranked economies. In the Smart Society subindex, high variations between countries, such as highly ranked South Korea and Sweden versus lower ranked Poland and Russia, resulted mostly from Poland and Russia's lack of willingness to use robots in manufacturing industry. On the other hand, the analysis has shown that the Good Chance Society subindex (10.01) does not show large variations between the ranked countries, from which, we can conclude that all analyzed economies invest sufficient efforts in the development of entrepreneurship and good business climate.

Table 5

Analysis of the range of variation and variance

\begin{tabular}{|l|l|l|l|l|l|}
\hline \multicolumn{1}{|c|}{ Comp. subindices } & \multicolumn{1}{c|}{ SmS } & \multicolumn{1}{c|}{ SGC } & NS & \multicolumn{1}{c|}{ KS } & \multicolumn{1}{c|}{ SuS } \\
\hline $\min$ & 9.04 & 8.63 & 11.38 & 14.27 & 12.12 \\
\hline $\max$ & 53.98 & 18.64 & 28.46 & 46.97 & 37.90 \\
\hline range of variation & 44.95 & 10.01 & 17.09 & 32.70 & 25.78 \\
\hline variance & 5726.66 & 7575.34 & 6425.63 & 5697.16 & 6925.67 \\
\hline
\end{tabular}




\begin{tabular}{|l|l|l|l|l|l|}
\hline standard deviation & 312.01 & 358.86 & 330.51 & 311.21 & 343.13 \\
\hline average value & 425 & 221 & 340 & 425 & 289 \\
\hline coefficient of variation & 0.73 & 1.62 & 0.97 & 0.73 & 1.19 \\
\hline
\end{tabular}

Source: the authors

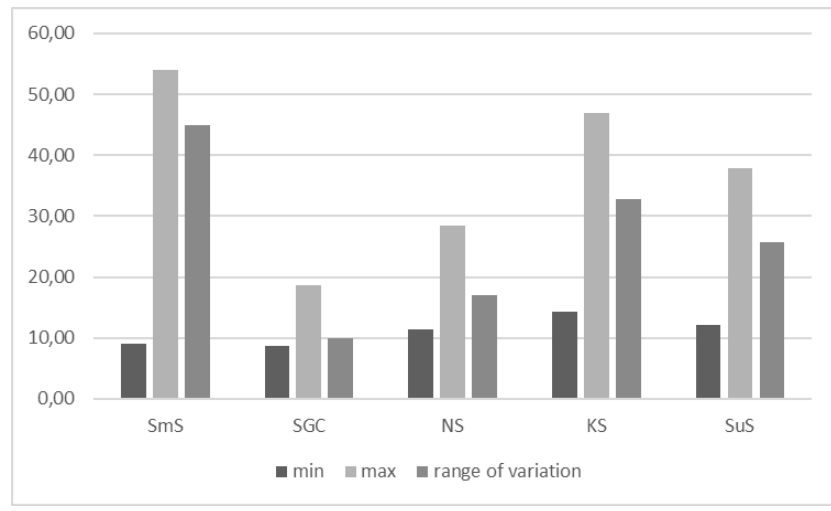

Figure 3

Range of variation

\section{Dilemmas and Reflections}

As the starting point of the research, the authors used the results of the previous work in which the classification of macroeconomic competitiveness indices was carried out, containing knowledge parameters in their model [7]. It can be seen that there are many models that are in some way related to the competitiveness of the knowledge society, but that they do not take into consideration the indicators of the new wave of change, i.e. the industry 4.0, and therefore are not suitable for measuring the national competitiveness of today's most developed countries, it was concluded in the previous works that qualitative indicators do not provide sufficiently objective results and that quantitative ones should be used as much as possible [7, 29]. In their further research, the authors developed a model for measuring the competitiveness of a knowledge-based society consisting of quantitative indicators. However, during development and advancement of technology, emerged the need to innovate the said model by incorporating new indicators reorienting to the demands of industry 4.0 [8]. In Table 1, an analysis of existing competitive models related to Industry 4.0 was implemented and among those three were found that measure competitiveness at the macro level. However, it has been found that they rely mainly on qualitative data and that there is a need to innovate competitiveness models in line with the requirements of Industry 4.0. From all of the above we can point out that we accept the main hypothesis of the 
paper which reads: The new model of competitiveness measurement presented in the paper provides a more adequate measurement of the position of today's most developed countries because it takes into consideration the challenges not only of the present but also of the future time, i.e. the fourth industrial revolution. The constructed index ranked 17 OECD countries using statistical methods of standardization, weighting and aggregation. The results showed that the Nordic countries like Norway, Sweden and Finland stood out, but also the success of the lands of the Asian Tigers i.e. South Korea, which ranked second.

Testing of the composite index was performed using the economic dynamism indicator. In this way it is shown how The Competitiveness Index of the Society 4.0 depends on a parameter such as GDP per capita. In fact, the differences between lower-ranked countries like China and Russia and those at the top Norway, USA, Sweden - have been found to be much greater when comparing economic indicators like GDP per capita than when ranking according to the parameters of a smart society. The differences in the ranking of some countries such as South Korea, which fell from the $1^{\text {st }}$ to the $8^{\text {th }}$ place upon crossing the parameters of economic dynamism, indicate the importance of using indicators that describe society in the context of industry 4.0. Namely, South Korea, although not at the top of the world in terms of economic performance, justifies its leadership by investing in the technologies and knowledge we need in the future, which is much more important today when measuring national competitiveness.

Furthermore, by conducting an analysis that determines the range in variations and variance for different composite index subindicators, it was found that there were differences between them. While, on one hand, in the subindicators Sustainable Society and the Networked Society, the ranges in variation and variance are pronounced, in the subindicators the Society of Good Chances, they much lower. Taking these data in consideration, as well as, the explanation given earlier in the paper, we can conclude that we accept the subhypothesis of the paper that reads: There are subindexes that have a small range of variation and variance, as well as those with more pronounced differences between the worst and the best ranked economy.

\section{Conclusions}

The study of the concept of Competitiveness, is a subject of increasing interest of Authors around the world, as the micro- and macro-environment becomes more complex and the number of factors, with multiple influences increase. That is why measuring and analyzing competitiveness today is vital for the creation of national and regional strategies and plans, as it is thus possible, to obtain guidance for tuning future development.

To more accurately measure the competitiveness of countries in the future, the authors believe that it is necessary to innovate existing models and introduce parameters such as: IoT devices online, Artificial Intelligence Index, use of industrial robots, 3D Printing Country Index, etc. This choice of indicators is 
particularly suitable for measuring the competitiveness of highly developed countries such as OECD members.

Although gross domestic product (GDP) per capita, was previously used as a major benchmark for success of a country, today, such an indicator can produce misinformation, due to the complexity of today's society in which we live. This paper establishes that there are several models that relate to the examination of competitiveness in the context of the Fourth Industrial Revolution at the macro level, but also that they mainly rely on qualitative data, which diminishes their objectivity. For this reason, the modeling of the composite Competitiveness Index of the Society 4.0 was performed, which was the aim of the paper.

When it comes to the limitations of the research, it is also worth pointing out that the current availability of data regarding the parameters describing the characteristics of the Fourth Industrial Revolution is quite low, and that in this respect there is a limitation in the use of the proposed model in terms of expansion of the country sample. However, the Authors believe that this limitation is only current and that the model will be able to be applied very quickly over a much wider range. Regarding directions for further research, it can be stated that in the coming period it is very important to constantly monitor the development of science and technology and gradually introduce new indicators that reflect this development. In the future, this could be, for example, an indicator measuring the number of autonomous vehicles or domestic robots. It is also necessary to constantly re-examine the role of certain weight values in the overall score and to change it according to the need. Also, research can be conducted at the regional level, of course, if relevant data are available.

The results provided by this model can be used in many applications, and above all, it would benefit all those who wish to quantify information and compare countries in terms of competitiveness in the coming $4^{\text {th }}$ Industrial Revolution. Also, the results may indicate that there are some negative trends in individual countries, which can be a good signal not to proceed with such trends. Although the survey is faced with limited availability of parameters, primarily with regard to the Smart Society subindex, the Authors believe that data availability will improve and the survey can be extended to a much larger range of countries. The authors believe that this paper significantly contributes to the work of all researchers engaged in the study of competitiveness, at the national level and even more so, in a broader sense, i.e. for those who can use and make use of these results in further research.

\section{References}

[1] Schwab, K.: The Fourth Industrial Revolution, Currency, 2017

[2] World Economic Forum: The Future of Jobs: Employment, Skills and Workforce Strategy for the Fourth Industrial Revolution, In Global Challenge Insight Report, World Economic Forum, Geneva, 2016 
[3] Pereira, A. C., Romero, F.: A Review of the Meanings and the Implications of the Industry 4.0 Concept, Procedia Manufacturing, Vol. 13, 2017, pp. 1206-1214

[4] Vaidya, S., Ambad, P., Bhosle, S.: Industry 4.0 - A Glimpse, Procedia Manufacturing, Vol. 20, 2018, pp. 233-238

[5] OECD: OECD Skills Outlook 2019: Thriving in a Digital World, OECD Publishing, Paris, 2019

[6] OECD: OECD Employment Outlook 2019: The Future of Work, OECD Publishing, Paris, 2019

[7] Katić, A., Ćosić, I., Anđelić, G., Raletić, S.: Review of Competitiveness Indices that Use Knowledge as a Criterion, Acta Polytechnica Hungarica Vol. 9, No. 5, 2012, pp. 25-45

[8] Katić, A., Kiš T., Ćosić I., Vukadinović S., Dobrodolac Šeregelj T.: Modelling the Composite Competitiveness Index of the Knowledge-Based Society, Acta Polytechnica Hungarica, Vol. 12, No. 1, 2015, pp. 229-249

[9] Katić, A., Ćosić, I., Kupusinac, A., Vasiljević, M., Stojić, I.: KnowledgeBased Competitiveness Indices and its Connection with Energy Indices, Thermal Science, Vol. 20, 2016, pp. 451-461

[10] Porter, M. E., Heppelmann, J. E.: How Smart, Connected Products are Transforming Competition, Harvard Business Review, 2014, Vol. 92, No. 11, pp. 64-88

[11] Porter, M. E., Heppelmann, J. E.: How Smart, Connected Products are Transforming Companies, Harvard Business Review. 2015, Vol. 93, No. 10, pp. $96-114$

[12] Drucker, P.: The Age of Discontinuity: Guidelines to our Changing Society, Routledge, 2017

[13] OECD: The Knowledge-Based Economy, OECD Publishing, Paris, 1996

[14] Nijkamp, P., Siedschlag, I.: Innovation, Growth and Competitiveness. Dynamic Regions in the Knowledge-Based World Economy, SpringerVerlag Berlin Heidelberg, 2011

[15] Porter, M., Stern, S.: The New Challenge to America's Prosperity: Findings from the Innovation Index. Council of Competitiveness, Washington DC, 1999

[16] Freudenberg, M.: Composite Indicators of Country Performance: a Critical Assessment, OECD Science, Technology and Industry Working Papers, 2003/26, OECD Publishing, Paris, 2003

[17] Sendler, U.: Industry 4.0 - Mastering Industrial Complexity with SysLM (in German), Springer, 2013, pp. 456 
[18] Kagermann, H., Wolfgang W., Johannes H.: Securing the Future of German Manufacturing Industry, Recommendations for Implementing the Strategic Initiative Industrie 4, No. 199, 2013

[19] Morrar, R., Arman, H., Mousa, S.: The Fourth Industrial Revolution (Industry 4.0): A Social Innovation Perspective, Technology Innovation Management Review, Vol. 7, No. 11, 2017, pp. 12-20

[20] Dutton, H. W.: Putting Things to Work: Social and Policy Challenges for the Internet of Things, Info, Vol. 16, No. 3, 2014, pp. 1-21

[21] Office for National Statistics: What are the Chances of Surviving to Age 100?, https://www.ons.gov.uk, 2016, Accessed on October 2019

[22] Okanovic, A.: Management of Competitiveness, Faculty of Technical Sciences, Novi Sad, Serbia, 2018

[23] Vacek, J.: On The Road: From Industry 4.0 to Society 4.0., Trendy v Podnikání, Vol. 7, No. 4, 2017, pp. 43-49

[24] Dujin, A., Geissler, C., Horstkötter, D.: Industry 4.0 The New Industrial Revolution - How Europe Will Succeed. Rol. Berger Strateg. Consult, 2014, pp. 1-24

[25] Basl, J., Doucek, P.: A Metamodel for Evaluating Enterprise Readiness in the Context of Industry 4.0., Information, 2019, Vol. 10, No. 89, doi:10.3390/info10030089

[26] Economic Development Board: The Singapore Smart Industry Readiness Index, Catalyzing the Transformation of Manufacturing, Economic Development Board, 2017

[27] Kearney, A. T.: Readiness for the Future of Production Report, The World Economic Forum, 2018

[28] Faarup J., Faarup A.: Global Industry 4.0 Readiness Report 2016, Danish Institute of Industry 4.0 (DII 4.0), 2017

[29] Katić, A., Ćosić, I., Anđelić, G.: Knowledge Based Competitiveness Indices and Position of Serbia, PSU-UNS International Conference on Engineering and Technology - ICET, Novi Sad, 2013

[30] Batchkova, A., Popov T., Ivanova A., Belev A.: Assessment of Readiness for Industry 4.0, International Scientific Journal "Industry 4.0", Vol. 3, No. 6, 2018, pp. 288-291

[31] Booysen, F.: An Overview and Evaluation of Composite Indices of Development, Social Indicators Research, Vol. 59, No. 2, 2002, pp. 115151

[32] Wang, Y., Ma, H. S., Yang, J. H., Wang, K. S.: Industry 4.0: A Way from Mass Customization to Mass Personalization Production, Advances in Manufacturing, Vol. 5, No. 4, 2017, pp. 311-320 
[33] Liu, C.: International Competitiveness and the 4. Industrial Revolution, Entrepreneurial Business and Economics Review, Vol. 5, No. 4, 2017, pp. $111-133$

[34] Xu, M., David, J. M., Kim, S. H.: The Fourth Industrial Revolution: Opportunities and Challenges, International Journal of Financial Research, Vol. 9, No. 2, 2018, pp. 90-95

[35] Guoping L., Yun H., Aizhi W.: Fourth Industrial Revolution: Technological Drivers, Impacts and Coping Methods, Chinese Geographical Science, Vol. 27, No. 4, 2017, pp. 626-637

[36] Peña-López, I.: OECD Digital Economy Outlook 2015, OECD Publishing, Paris, 2015

[37] OECD: Key emerging technologies, OECD Publishing, Paris, 2017

[38] Shoham, Y., Perrault, R., Brynjolfsson, E., Clark, J., LeGassick, C.: Artificial Intelligence Index 2017 Annual Report, Artificial Intelligence Index, 2017

[39] Miller, H., Stirling, R., Chung, Y., Lokanathan, S., Martinho-Truswell, E., New, J., Rutenberg, I., Scrollini, F.: Government Artificial Intelligence Readiness Index 2019, Oxford Insights, 2019

[40] Threlfall, R.: Autonomous Vehicles Readiness Index, Klynveld Peat Marwick Goerdeler (KPMG) International, 2019

[41] Open Charge Map: The Global Public Registry of Electric Vehicle Charging Locations, https://openchargemap.org/site/, Accessed on September 2019

[42] Unit EI. The Automation Readiness Index: Who is Ready for the Coming Wave of Automation?. London: Economist Intelligence Unit. 2018

[43] OECD: ICT Access and Usage by Businesses (database), http://oe.cd/bus, Accessed on September 2019

[44] HP: 3D Printing: Ensuring Manufacturing Leadership in the $21^{\text {st }}$ Century, HP, 2018

[45] International Federation of Robotics: Robot Density by Country 2016, https://ifr.org/, Accessed on September 2019

[46] The World Bank Group: https://data.worldbank.org/, Accessed on September 2019

[47] OECD: Telecommunications and Internet Statistics: Broadband database, https://data.oecd.org/, Accessed on September 2019

[48] Zhenmin L.: United Nations E-Government Surveys: Gearing EGovernment to Support Transformation Towards Sustainable and Resilient Societies, United Nations, New York, 2018 
[49] Zavazava, C.: ICT Prices 2017, International Telecommunication Union, Geneva Switzerland, 2017

[50] Appfigures: Indicator: Countries releasing most app, https://appfigures.com/explorer/datasets, Accessed on September 2019

[51] Kässi, O., Lehdonvirta, V.: Online Labour Index: Measuring the Online Gig Economy for Policy and Research, Technological Forecasting and Social Change, Vol. 137, 2018, pp. 241-248

[52] OECD: https://data.oecd.org/, Accessed on September 2019

[53] UNESCO Institute for Statistics: http://data.uis.unesco.org/, Accessed on September 2019

[54] Eurostat: Indicator: Employment in technology and knowledge-intensive sectors at the national level, http://appsso.eurostat.ec.europa.eu/, Accessed on September 2019

[55] World Intellectual Property Organization: World Intellectual Property Indicators 2018, World Intellectual Property Organization, 2018

[56] Eurostat: Indicator: Recycling rate of municipal waste in \%, https://ec.europa.eu/, Accessed on September 2019

[57] Pariona, A.: OECD Recycling Statistics, World Atlas, https://www.worldatlas.com/, Accessed on September 2019

[58] OECD: List of OECD Member countries, https://www.oecd.org/, Accessed on September 2019

[59] Porter, M., Stern, S.: The New Challenge to America's Prosperity: Findings from the Innovation Index, Council of Competitiveness, Washington DC, 1999 